\title{
Manganese Oxide Formation in Lanthanum Strontium Manganite-Yttria-Stabilized Zirconia SOFC Cathodes
}

\author{
HSIANG-JEN WANG, MARK R. DE GUIRE, ZHENGLIANG XING, GERRY AGNEW, \\ RICHARD GOETTLER, ZHIEN LIU, and ARTHUR H. HEUER
}

\begin{abstract}
Microstructural changes in the cathode adjacent to the cathode-electrolyte interface were studied in SOFCs with lanthanum strontium manganite (LSM) $/ \mathrm{Y}_{2} \mathrm{O}_{3}$-stabilized $\mathrm{ZrO}_{2}$ (YSZ) composite cathodes after long-term operation ( 1.3 to $2.0 \mathrm{kh})$ with steam $\left(1\right.$ to 3 pct $\left.\mathrm{H}_{2} \mathrm{O}\right)$ added to the cathode gas. We specifically sought to understand why the degradation rate (the increase of area specific resistance with time) was markedly higher at lower temperatures (e.g., $1073 \mathrm{~K}$ $\left.\left(800{ }^{\circ} \mathrm{C}\right)\right)$ than at higher temperatures $\left(\right.$ e.g., $\left.1198 \mathrm{~K}\left(925^{\circ} \mathrm{C}\right)\right)$. Transmission electron microscopy, combined with X-ray energy-dispersive spectroscopy and electron energy-loss spectroscopy, was used to detect and identify submicron $\mathrm{Mn}_{\mathrm{x}} \mathrm{O}_{\mathrm{y}}$ precipitates. The particles were shown to be $\mathrm{Mn}_{3} \mathrm{O}_{4}$ in cells operated at $1198 \mathrm{~K}\left(925^{\circ} \mathrm{C}\right)$, and both $\mathrm{Mn}_{3} \mathrm{O}_{4}$ and $\mathrm{Mn}_{2} \mathrm{O}_{3}$ in cells operated at $1073 \mathrm{~K}\left(800{ }^{\circ} \mathrm{C}\right)$. In a cell exposed for $5 \mathrm{kh}$ at $1198 \mathrm{~K}\left(925^{\circ} \mathrm{C}\right)$ to a cathode atmosphere of 1.1 pet $\mathrm{H}_{2} \mathrm{O}$ at 4 bara, $\mathrm{Mn}_{\mathrm{x}} \mathrm{O}_{\mathrm{y}}$ precipitates were uniformly distributed across the cathode. On the other hand, in an identical cell exposed to the same conditions but operated continuously at $380 \mathrm{~mA} \mathrm{~cm}{ }^{-2}, \mathrm{Mn}_{\mathrm{x}} \mathrm{O}_{\mathrm{y}}$ precipitates were observed almost exclusively within about $3 \mu \mathrm{m}$ of the electrolyte/cathode interface. Whether $\mathrm{Mn}_{\mathrm{x}} \mathrm{O}_{\mathrm{y}}$ formation is causative or simply correlative with the steam effect remains an important question for future work.
\end{abstract}

DOI: $10.1007 / \mathrm{s} 40553-014-0026-5$

(c) LG Fuel Cell Systems, Inc. 2014

\section{INTRODUCTION}

FUEL cells offer the following advantages compared to conventional power sources: higher efficiencies, lower emissions, modular installation scalable from milliwatts to megawatts, and distributed power generation to reduce transmission losses. ${ }^{[1,2]}$ Fuel cells have produced billions of kilowatt-hours of electrical energy in stationary and mobile applications all over the world.

Among fuel cell technologies, solid oxide fuel cells (SOFCs) offer unique benefits: ${ }^{[3]}$ they run not only on hydrogen but also on widely available hydrocarbon fuel; they need little or no precious metal catalysts; they provide high-quality utility-grade heat, which, in combination with electrical efficiencies of up to $60 \mathrm{pct}$, leads to total system efficiencies of 80 to 85 pct; and they can be run in reverse as electrolysis cells-i.e., using electricity to produce hydrogen from water-making them both an energy-conversion and an energy-storage technology.

Electrical losses at the cathode in SOFCs with LSM-based ([ $\left.\mathrm{La}_{1-x} \mathrm{Sr}_{x}\right]_{y} \mathrm{MnO}_{3 \pm z}$, perovskite structure)

HSIANG-JEN WANG, Senior Research Associate, MARK R. DE GUIRE, Associate Professor, and ARTHUR H. HEUER, Distinguished University Professor and Kyocera Professor, are with the Department of Materials Science and Engineering, Case Western Reserve University, Cleveland, OH 44106. Contact e-mail: mrd2@ case.edu ZHENGLIANG XING, Engineer, GERRY AGNEW, Chief Technologist, RICHARD GOETTLER, Manager, and ZHIEN LIU, Development Lead, are with LG Fuel Cell Systems Inc., North Canton, OH 44720.

Manuscript submitted January 31, 2014.

Article published online August 9, 2014 cathodes operating at the lower end of the useful temperature range are a significant technical limitation, ${ }^{[4]}$ as indicated by measurements of area specific resistance (ASR) in single "button" cells (Figure 1). ${ }^{[5]}$ The cathode reaction requires an electronic conductor (LSM), an ionic conductor, often $\mathrm{Y}_{2} \mathrm{O}_{3}$-stabilized or $\mathrm{Sc}_{2} \mathrm{O}_{3}$-stabilized $\mathrm{ZrO}_{2}$ (YSZ or ScSZ), and oxygen gas to meet at the so-called three-phase boundaries (TPB). In the current work, cells consisted of porous LSM/zirconia composite cathodes, a stabilized zirconia electrolyte, and $\mathrm{Ni}$ /zirconia anodes.

LSM exhibits negligible ionic conductivity. ${ }^{[3,6]}$ This confines the TPB within the composite cathode to a thin surface region near the physical boundary between the LSM, the ionic $\mathrm{ZrO}_{2}$-based conductor, and the pore. For SOFC systems close to commercial deployment, LSM-based cathodes have received considerable attention for their thermo-mechanical and chemical compatibility with other cell components, and for their longterm stability in the intended operating environment.

A significant mode of degradation of LSM/YSZ composite cathodes occurs when the hot exhaust from the cell stacks, which can include several percent by weight of water vapor, is used to pre-heat the incoming reactants and increase the overall system efficiency. ${ }^{[7-12]}$ Under these conditions, an increase in ASR occurs below $1173 \mathrm{~K}\left(900^{\circ} \mathrm{C}\right)^{[8-12]}$ but not above this temperature $^{[8,12]}$ The ASR rise on introduction of humidity consists of an initial fast transient followed by a slower increase..$^{[8,9,11,12]}$ The effect is seen in cathodes of LSM with Gd-doped $\mathrm{CeO}_{2}$ (GDC) ${ }^{[11]}$ but not in cathodes of (La,Sr,Co) ferrite (LSCF) with GDC. ${ }^{[9]}$ This difference 


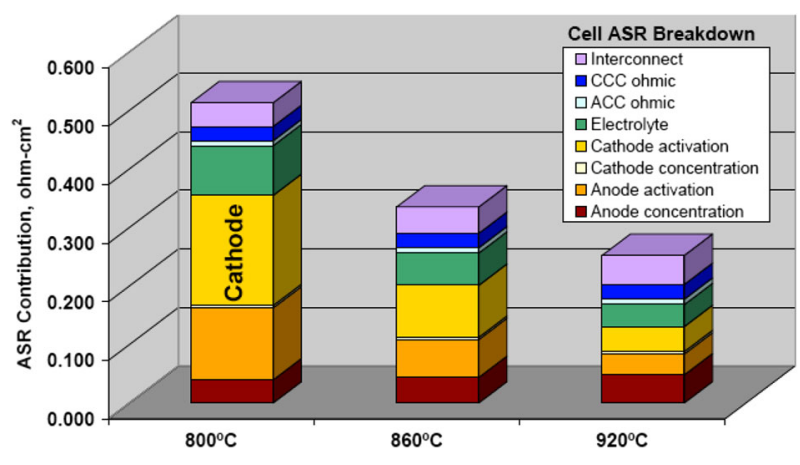

Fig. 1-(color figure online). Contributions to electrical losses (area specific resistance, ASR) from various active layers in LG Fuel Cell Systems (LGFCS) single "button" SOFCs at $1073 \mathrm{~K}, 1133 \mathrm{~K}$, and $1193 \mathrm{~K}\left(800{ }^{\circ} \mathrm{C}, 860^{\circ} \mathrm{C}\right.$, and $\left.920^{\circ} \mathrm{C}\right) \cdot{ }^{[5]} \mathrm{CCC}$ : cathode current collector. ACC: anode current collector. (C2014 LG Fuel Cell Systems Inc. Used with permission.

might be associated with the surface oxygen exchange rate, which has been reported to be temperature dependent for LSM, but relatively independent of temperature for LSCF. ${ }^{[13]}$

The rate of ASR rise increases with increasing current density $\left(0.25-0.75 \mathrm{~A} \mathrm{~cm}^{-2}\right) .^{[9]}$ Lower ASR can be restored by operating the cell in dry cathode air, ${ }^{[7,9-11]}$ but the extent of this reversibility varies with specific test conditions. For example, it has been reported ${ }^{9]}$ that the ASR rise was only partially reversed on removal of $\mathrm{H}_{2} \mathrm{O}$ from the cathode gas at $1023 \mathrm{~K}\left(750^{\circ} \mathrm{C}\right)$, and that at levels of humidity below $\sim 5$ pct, the effect appeared to depend on current density and temperature. In that study ${ }^{[9]}$ the ASR increased linearly at $1023 \mathrm{~K}\left(750{ }^{\circ} \mathrm{C}\right)$ for 0 to 12.8 pct humidity at $0.41 \mathrm{~A} \mathrm{~cm}^{-2}$, whereas others ${ }^{[8]}$ reported no ASR rise with 3 pet humidity at $1073 \mathrm{~K}\left(800{ }^{\circ} \mathrm{C}\right)$ and $0.200 \mathrm{~A} \mathrm{~cm}^{-2}$. The details of the "steam effect" (and cathode losses in general) also depend on the composition of the LSM.

Two of the salient characteristics of the steam effect thus are that in humid atmospheres, a fast and then a slow rise in ASR is observed at lower temperatures (e.g., $1048 \mathrm{~K}\left(775^{\circ} \mathrm{C}\right)$ ), but not at higher temperatures (e.g., $1173 \mathrm{~K}\left(900^{\circ} \mathrm{C}\right)$ ), and that the pre-steam values of ASR can be restored by running the cell at these higher temperatures.

One mechanism inferred for the steam effect was based on electrical impedance spectroscopy (EIS) studies. ${ }^{[12]} \mathrm{Mn}$ normally diffuses $\left(\right.$ as $\mathrm{Mn}^{2+}$ ) in dry air from LSM into adjacent YSZ, whereas in moist air, a reaction product is formed between the LSM and the YSZ (the "fast" effect). During prolonged humidification (the "slow" effect), the Mn volatilizes, causing decomposition at the LSM surface and hindering both the adsorption of oxygen on the LSM and the charge transfer at the interface. Microstructural evidence for such a mechanism was obtained by etching the LSM out of the cathode, revealing craters in the electrolyte surface that were attributed to formation of a reaction product at the LSM-electrolyte interface.

The current work explores the possibility that the rise in ASR of LSM-YSZ SOFC cathodes during long-term operation under practical conditions is connected to microstructural changes, specifically to the phase stability of the LSM. The imaging and microanalysis techniques used here leave the critical YSZ-LSM interface intact and provide more detailed views of the chemical changes that took place there during cell operation.

The ASR of SOFCs was monitored during practical operating conditions that either did, or did not, elicit the steam effect. After cell operation, the microstructural changes in these cathodes were studied using transmission electron microscopy (TEM), X-ray energy-dispersive spectroscopy (XEDS), and electron energy-loss spectroscopy (EELS). In a previous study, the use of EELS to determine the valence state of Mn in the LSM phase of SOFC cathodes was validated by X-ray photoelectron spectroscopy (XPS). ${ }^{[14]}$ In the present study, EELS was used as a "fingerprint" method to identify the specific manganese oxide phases observed in the cathodes after operation.

\section{EXPERIMENTAL PROCEDURES}

\section{A. SOFC Fabrication and Testing}

The LSM-3YSZ composite cathodes in the cells described in Figures 2 through 7 contained LSM of the same nominal A-site-deficient composition (proprietary to LG Fuel Cell Systems Inc.) and acquired from a major US fuel cell materials supplier. Electrolyte-supported button cells were made using $\mathrm{ZrO}_{2}$ with $3 \mathrm{~mol}$ pct $\mathrm{Y}_{2} \mathrm{O}_{3}$ (3YSZ) or $6 \mathrm{~mol}$ pct $\mathrm{Sc}_{2} \mathrm{O}_{3}(6 \mathrm{ScSZ})$ as electrolyte. For cathode-symmetric cells, LSM-YSZ electrodes and LSM current collector layers were screen-printed onto both sides of pre-fired electrolyte disks, and then co-fired at $1418 \mathrm{~K}\left(1145^{\circ} \mathrm{C}\right)$. Subscale cells (one cell, or five cells connected in series) with segmented-in-series design were fabricated by screen printing the anode (NiO-YSZ), electrolyte, and cathode onto porous inert ceramic tubes. (The $\mathrm{NiO}$ was subsequently reduced to Ni.) Anode and cathode current collector layers were also deposited onto anode and cathode sides, respectively, to reduce in-plane resistance. Subscale cells were operated in air or diluted air with $\mathrm{H}_{2} \mathrm{O}$ contents ranging from 0 to 3 pct under constant current (380 to $480 \mathrm{~mA} \mathrm{~cm}{ }^{-2}$ ) at constant temperature $\left(1048 \mathrm{~K}\right.$ to $1198 \mathrm{~K}\left(775^{\circ} \mathrm{C}\right.$ to $\left.925^{\circ} \mathrm{C}\right)$, controlled by the testing furnace). Cell ASR was calculated as the difference between open cell voltage and the operating voltage, divided by current density.

Total electrode polarization was obtained from subscale cells. The cathode contribution to the total electrode polarization was deduced through AC impedance measurements on cathode-symmetric cells tested under similar conditions. AC impedance was measured using a Solartron 1470 multi-channel potentiostat and 1255B frequency response analyzer.

\section{B. Microstructural Characterization}

TEM thin foils were taken from the cathode/electrolyte interface using a focused ion beam (FIB) milling technique and standard in situ lift-out procedure in a 


\begin{tabular}{|c||c|c|c|}
\hline segment & $T, \mathrm{~K}\left(T,{ }^{\circ} \mathrm{C}\right)$ & $\begin{array}{c}\text { cathode } \\
\% \mathrm{O}_{2}\end{array}$ & $\begin{array}{c}\text { cathode } \\
\% \mathrm{H}_{2} \mathrm{O}\end{array}$ \\
\hline \hline A & $1173(900)$ & 12 & dry \\
\hline B & $1123(850)$ & 12 & dry \\
\hline C & $1048(775)$ & 12 & dry \\
\hline D & $1048(775)$ & 12 & 3 \\
\hline E & \multicolumn{3}{|c|}{ shutdown for cell repair } \\
\hline F & $1173(900)$ & 12 & 3 \\
\hline G & $1048(775)$ & 12 & dry \\
\hline
\end{tabular}

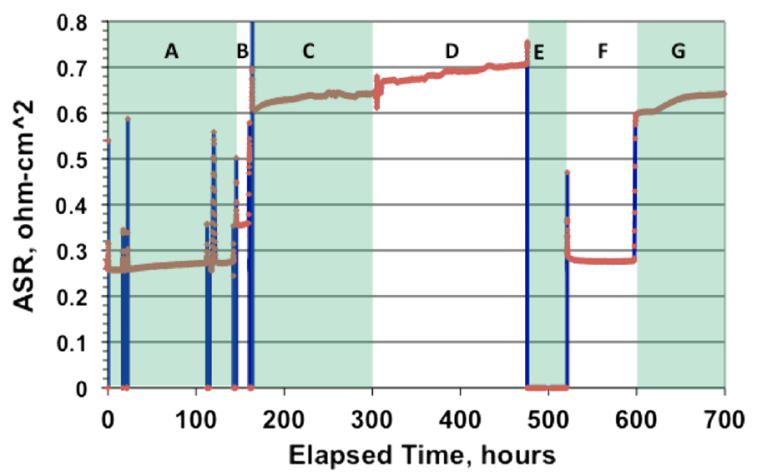

Fig. 2 -(color figure online). ASR changes during testing at $450 \mathrm{~mA} \mathrm{~cm}$ at the indicated temperatures and atmospheres. (C2014 LG Fuel Cell Systems Inc. Used with permission.

FEI Quanta 3D scanning electron microscope (SEM). A probe of $100 \mathrm{pA}$ beam current at $30 \mathrm{kV}$ accelerating voltage was used for final polishing.

The microstructures of the SOFC specimens were examined in a high-resolution (S)TEM (Zeiss Libra 200 (S)TEM), operated at $200 \mathrm{keV}$ with a heated Schottky field-emission cathode and equipped with an in-column Omega electron energy filter. Elemental analysis was performed with XEDS using both point- and linescanning mode. All concentration profiles were plotted using cation percentage by excluding the oxygen content. Elemental distribution maps were acquired in the spectrum imaging (SI) mode. Phase maps were constructed by superimposing individual $\mathrm{Zr}$ (red), La (blue), and $\mathrm{Mn}$ (green) maps. EELS spectra of the $\mathrm{O}-K$ and $\mathrm{Mn}-L_{2,3}$ edges were used to identify specific manganese oxide phases. All the EELS spectra were acquired with the in-column Omega filter in spectrum mode using a CCD camera with $2 \mathrm{k} \times 2 \mathrm{k}$ resolution. The same background-subtracted window was applied to all spectra $^{[15,16]}$ using the Pearson method. ${ }^{[1]]}$

\section{RESULTS AND DISCUSSION}

Figure 2 shows typical results of the steam effect in a test on a single cell operated at $450 \mathrm{~mA} \mathrm{~cm}^{-2}$. In dry cathode gas, ASR jumped within minutes when temperature was decreased from $1173 \mathrm{~K}\left(900{ }^{\circ} \mathrm{C}\right.$, segment A) to $1123 \mathrm{~K}\left(850^{\circ} \mathrm{C}\right.$, segment $\left.\mathrm{B}\right)$ and then again from $1123 \mathrm{~K}$ to $1048 \mathrm{~K}\left(850{ }^{\circ} \mathrm{C}\right.$ to $775^{\circ} \mathrm{C}$, segment $\left.\mathrm{C}\right)$. This reflects the normal effects of both slower reaction kinetics and lower ionic conductivity (higher activation and ohmic polarizations, respectively) at lower temperatures. Between temperature changes, the ASR rose slowly at constant operating temperature, even without added humidity. When 3 pct $\mathrm{H}_{2} \mathrm{O}$ was added to the cathode atmosphere at $1048 \mathrm{~K}\left(775^{\circ} \mathrm{C}\right.$, segment D), an additional almost instantaneous rise in ASR occurred, followed by a slower rise (though faster than the slow rise seen in dry air). In segment E, the test was shut down for repair of the cell. On raising the temperature again to $1173 \mathrm{~K}\left(900{ }^{\circ} \mathrm{C}\right)$, but keeping the $\mathrm{H}_{2} \mathrm{O}$ content at 3 pct (segment F), the ASR rapidly returned almost to its previous $1173 \mathrm{~K}\left(900{ }^{\circ} \mathrm{C}\right) /$ dry air value (segment
A) and was nearly constant thereafter. On lowering the temperature to $1048 \mathrm{~K}\left(775^{\circ} \mathrm{C}\right)$ in dry air (segment $\mathrm{G}$ ), the ASR behavior was almost identical to that exhibited prior to $\mathrm{H}_{2} \mathrm{O}$ exposure (segment $\mathrm{C}$ ). That is, under these conditions, the steam effect was essentially completely reversible.

To further examine the role of temperature in the steam effect, two subscale cells (five cells connected in series) were tested at $400 \mathrm{~mA} \mathrm{~cm}{ }^{-2}$ under constant current control mode, one at $1198 \mathrm{~K}\left(925^{\circ} \mathrm{C}\right)$ and one at $1073 \mathrm{~K}$ $\left(800{ }^{\circ} \mathrm{C}\right)$, with cathode gas containing 1 to 3 pct $\mathrm{H}_{2} \mathrm{O}$. Plots of ASR vs time (Figure 3) revealed that the degradation rate at $1198 \mathrm{~K}\left(925^{\circ} \mathrm{C}\right)\left(0.004 \Omega \mathrm{cm}^{2} \mathrm{kh}^{-1}\right)$ was an order of magnitude lower than at $1073 \mathrm{~K}\left(800^{\circ} \mathrm{C}\right)$ $\left(0.04 \Omega \mathrm{cm}^{2} \mathrm{kh}^{-1}\right)$. During a 48 -h excursion at $1048 \mathrm{~K}$ $\left(775^{\circ} \mathrm{C}\right)$, the ASR rose at an even higher rate $\left(0.2 \Omega \mathrm{cm}^{2} \mathrm{kh}^{-1}\right)$. This finding is consistent with prior reports that, relative to dry cathode air, the increase in degradation rate in humid cathode atmospheres is significant at temperatures below $1173 \mathrm{~K}\left(900{ }^{\circ} \mathrm{C}\right)^{[8-12]}$ but essentially absent at higher temperatures. ${ }^{[8,12]}$

Figure 4 shows TEM images of two cathodes after operation in humid air, one at $1198 \mathrm{~K}\left(925^{\circ} \mathrm{C}\right)$ (top) and one at $1073 \mathrm{~K}\left(800^{\circ} \mathrm{C}\right)$ (bottom). The dark-field scanning transmission electron microscopy (DF-STEM) images of the cathode/electrolyte interface are at the left, and the corresponding XEDS elemental maps at the right. The porous LSM/YSZ composite cathode (the major portion of the images) and the dense YSZ electrolyte (far left) are clearly observed. XEDS elemental mapping showed several submicron Mn-rich precipitates (green areas) in the cathodes of both cells, especially near the cathode-electrolyte interface.

The STEM-EDS technique yielded detailed chemical information about these $\mathrm{Mn}$-containing precipitates. Figure 5 shows a representative DF-STEM image, its corresponding superimposed elemental map depicting the line scan location, and the cation concentration profile of the $1198 \mathrm{~K}\left(925^{\circ} \mathrm{C}\right)$ cell of Figures 3(a) and 4. These precipitates primarily contain $\mathrm{Mn}$ and $\mathrm{O}$ with only a minor concentration of other elements; they are essentially $\mathrm{Mn}_{\mathrm{x}} \mathrm{O}_{\mathrm{y}}$ precipitates. Similar results were obtained from other precipitates in the cells described here.

Figure 6 shows the background-subtracted EELS $\mathrm{O}-K$ and $\mathrm{Mn}-L_{2,3}$ spectra acquired from two $\mathrm{Mn}_{\mathrm{x}} \mathrm{O}_{\mathrm{y}}$ 


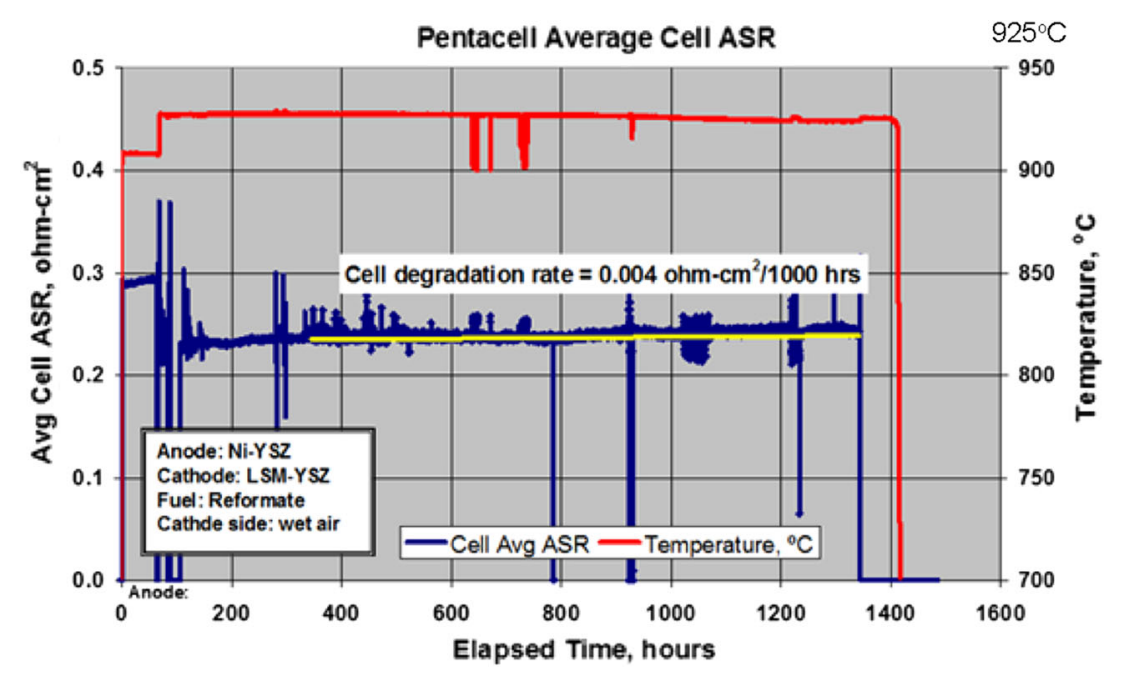

(a)

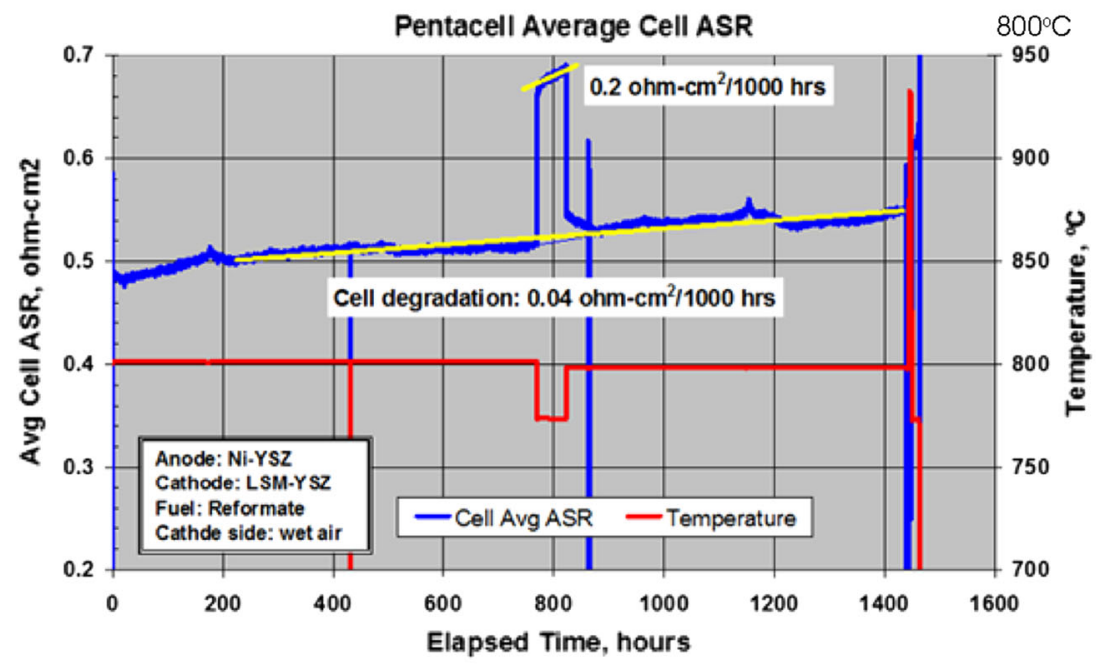

(b)

Fig. 3 - (color figure online). Cell ASR with $\mathrm{H}_{2} \mathrm{O}$ in cathode environment as a function of operating temperature: (a) $1198 \mathrm{~K}\left(925{ }^{\circ} \mathrm{C}\right)$, $480 \mathrm{~mA} \mathrm{~cm}^{-2}$; (b) $1073 \mathrm{~K}\left(800{ }^{\circ} \mathrm{C}\right), 400 \mathrm{~mA} \mathrm{~cm}{ }^{-2}$. Both cells tested with reformate at the anode. @2014 LG Fuel Cell Systems Inc. Used with permission.

precipitates (identified as grain 1 and grain 2) in the cell operated at $1073 \mathrm{~K}\left(800^{\circ} \mathrm{C}\right)$. The $\mathrm{O}-\mathrm{K}$ edge was selected for electronic fine structure analysis because its variation among different $\mathrm{Mn}_{\mathrm{x}} \mathrm{O}_{\mathrm{y}}$ phases is well documented. ${ }^{[18]}$ Also, the Mn- $L_{2,3}$ edge can be used to confirm the identity of the $\mathrm{Mn}_{\mathrm{x}} \mathrm{O}_{\mathrm{y}}$ phase. The resemblances of the shape of the $\mathrm{O}-K$ edge between grain 1 and $\mathrm{Mn}_{2} \mathrm{O}_{3}$, and between grain 2 and $\mathrm{Mn}_{3} \mathrm{O}_{4}$, are clear. Similarly, the acquired $\mathrm{Mn}-L_{2,3}$ edges of grain 1 and grain 2 resemble the ones reported for $\mathrm{Mn}_{2} \mathrm{O}_{3}$ and $\mathrm{Mn}_{3} \mathrm{O}_{4}$. Finally, Table I shows the measured edge positions and calculated $L_{3} / L_{2}$ ratio of the $\mathrm{Mn}-L_{2,3}$ edge ${ }^{[19]}$ and confirms the identification of the $\mathrm{Mn}_{\mathrm{x}} \mathrm{O}_{\mathrm{y}}$ phases present in grains 1 and 2 of Figure 6. Clearly, both $\mathrm{Mn}_{3} \mathrm{O}_{4}$ and $\mathrm{Mn}_{2} \mathrm{O}_{3}$ formed in the cells tested at $1073 \mathrm{~K}\left(800^{\circ} \mathrm{C}\right)$.

The EELS study was further carried out on all the $\mathrm{Mn}_{\mathrm{x}} \mathrm{O}_{\mathrm{y}}$ precipitates in TEM foils in both cells. In the cell of Figures 3(a), 4 (top), and 5, which was tested under conditions that showed no steam effect $\left(1198 \mathrm{~K}\left(925^{\circ} \mathrm{C}\right)\right.$, 1.2 pet $\mathrm{H}_{2} \mathrm{O}$, only $0.004 \Omega \mathrm{cm}^{2}$ rise in ASR per kh), only $\mathrm{Mn}_{3} \mathrm{O}_{4}$ was present (Figure 7a), whereas both $\mathrm{Mn}_{3} \mathrm{O}_{4}$ and $\mathrm{Mn}_{2} \mathrm{O}_{3}$ were observed (Figure 7b) in the cell of Figure 6, which was tested under conditions that showed a significant steam effect $\left(1073 \mathrm{~K}\left(800{ }^{\circ} \mathrm{C}\right), 1.2\right.$ pct $\mathrm{H}_{2} \mathrm{O}$, $0.05 \Omega \mathrm{cm}^{2}$ rise in ASR in the first 500 hours, followed by a rise of $0.03 \Omega \mathrm{cm}^{2}$ from 1000 to 2000 hours).

The appearance of $\mathrm{Mn}_{2} \mathrm{O}_{3}$ in the cell tested at lower temperature in Figure 7(b) is consistent with general trends towards higher oxidation states with decreasing temperature in transition metal oxides. ${ }^{[20]}$ Further, our earlier work $^{[14]}$ showed that the average valence of $\mathrm{Mn}$ in the LSM phase near the cathode-electrolyte interface increased from $3.38 \pm 0.11$ in the as-fabricated cell (fired at $1418 \mathrm{~K}\left(1145^{\circ} \mathrm{C}\right)$ ) to $3.59 \pm 0.07$ after operation at $1048 \mathrm{~K}\left(775^{\circ} \mathrm{C}\right)$ for 214 hours in air with 3 to 4 pct $\mathrm{H}_{2} \mathrm{O}$. The specific $\mathrm{Mn}_{\mathrm{x}} \mathrm{O}_{\mathrm{y}}$ phases observed in 


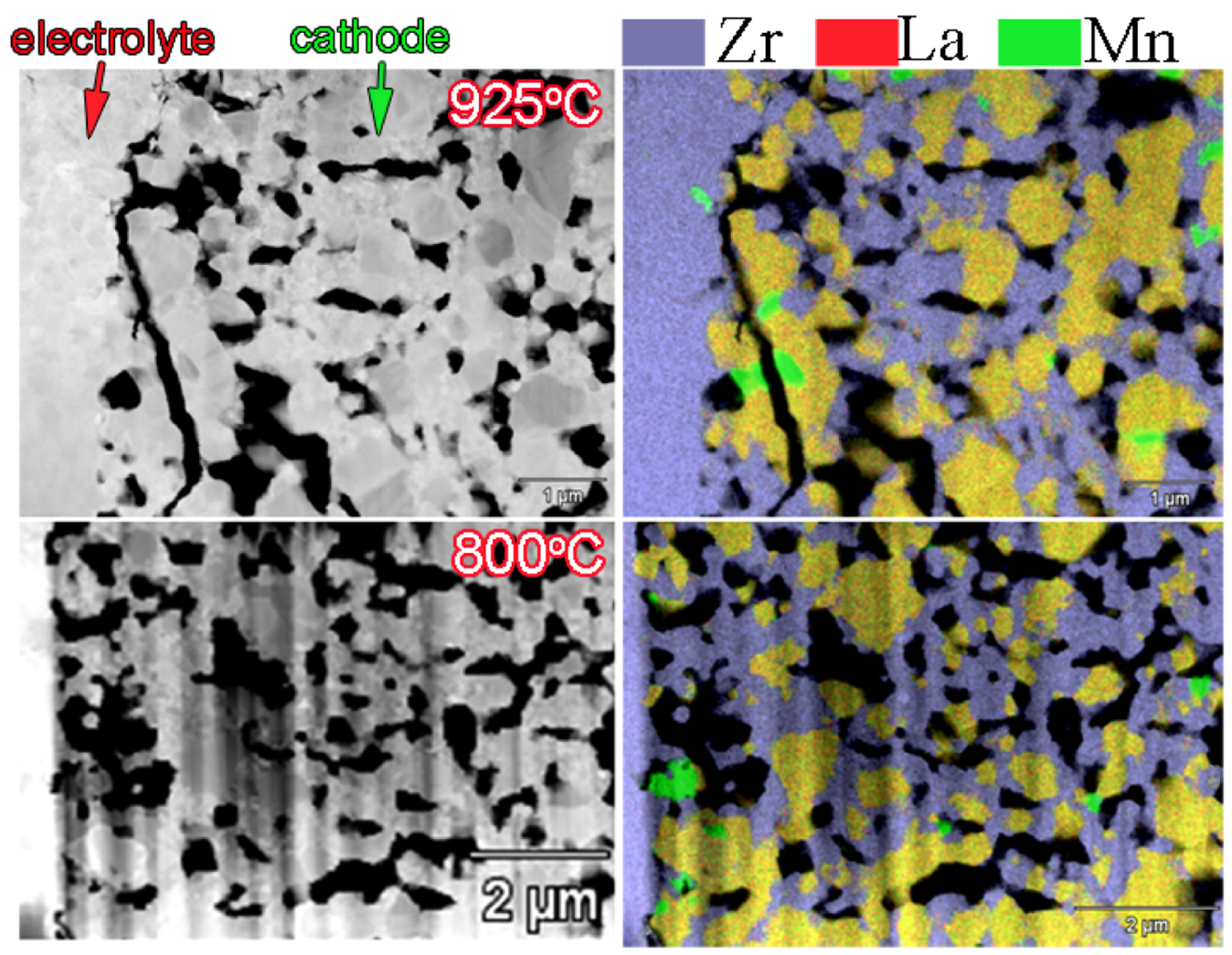

Fig. 4 -(color figure online). Left: DF-STEM images across electrolyte (YSZ)/cathode (LSM + YSZ) interface of SOFCs operated at $1198 \mathrm{~K}$ $\left(925^{\circ} \mathrm{C}\right)$ (top) and $1073 \mathrm{~K}\left(800{ }^{\circ} \mathrm{C}\right)$ (bottom) in humid air on the cathode side. Right: Corresponding elemental maps, constructed by superimposing $\mathrm{Zr}$ (blue), La (red), and $\mathrm{Mn}$ (green) maps (so that the LSM phase appears yellow). (The vertical stripes in the $1073 \mathrm{~K}\left(800{ }^{\circ} \mathrm{C}\right.$ ) images are "curtaining" artifacts originating from porosity during FIB foil preparation.).
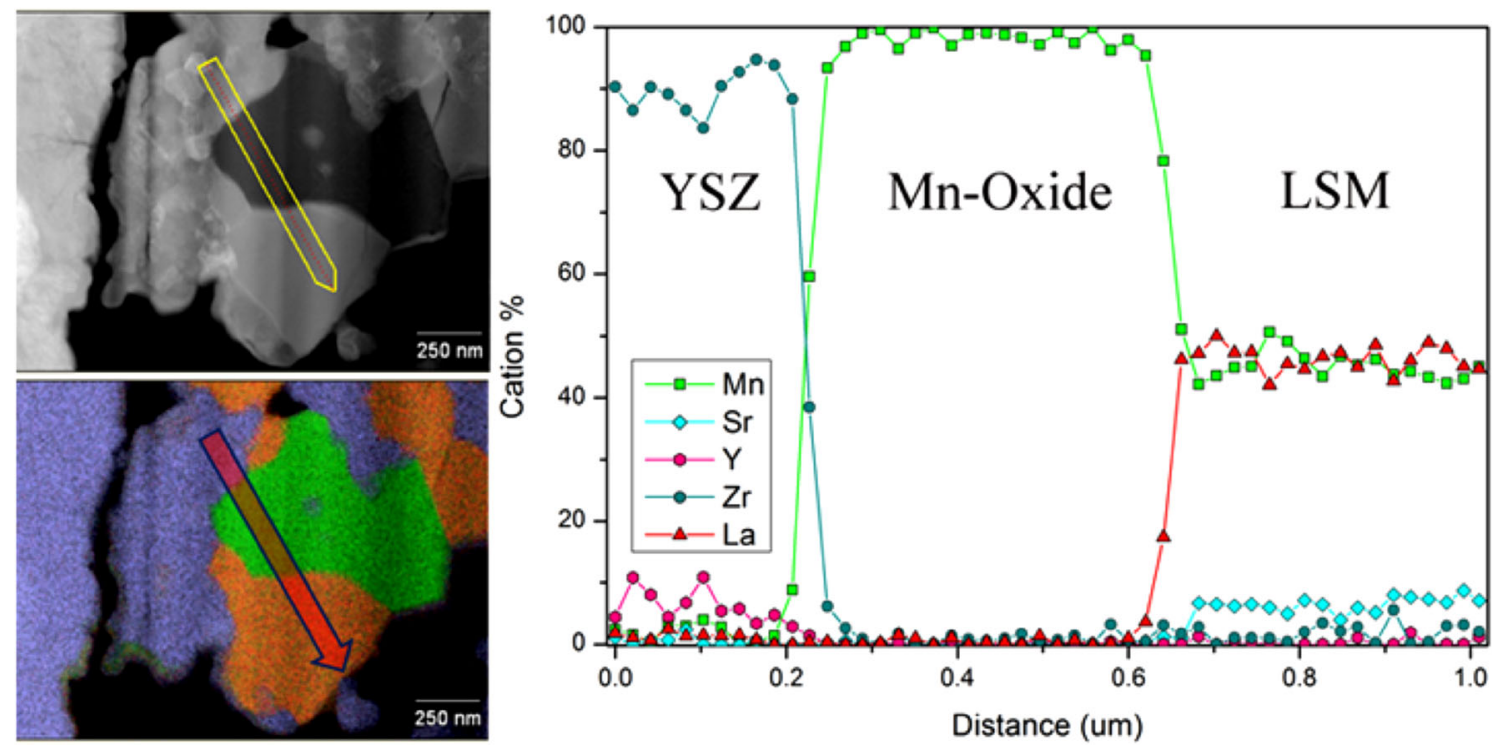

Fig. 5-(color figure online). DF-STEM image (upper left), XEDS elemental map (lower left), and the elemental concentration profiles (right) acquired across YSZ/Mn-oxide/LSM phases along the indicated arrow, in the cell in Figs. 3 and 4 that was operated at $1198 \mathrm{~K}\left(925^{\circ} \mathrm{C}\right)$.

Figure 7 are also consistent with reported $\mathrm{Zr}-\mathrm{Y}-\mathrm{Mn}-\mathrm{O}$ phase equilibria ${ }^{[21]}$ and with detailed thermodynamic calculations $^{[22]}$ on LSM over the relevant range of temperatures and $p_{\mathrm{O}_{2}}$.
Mn-rich LSM compositions are used in SOFCs to decrease the tendency of LSM to react with the zirconia (either in the electrolyte or in the LSM-YSZ cathode) to form insulating $\mathrm{La}_{2} \mathrm{Zr}_{2} \mathrm{O}_{7}$ pyrochlore or $\mathrm{SrZrO}_{3}$ 

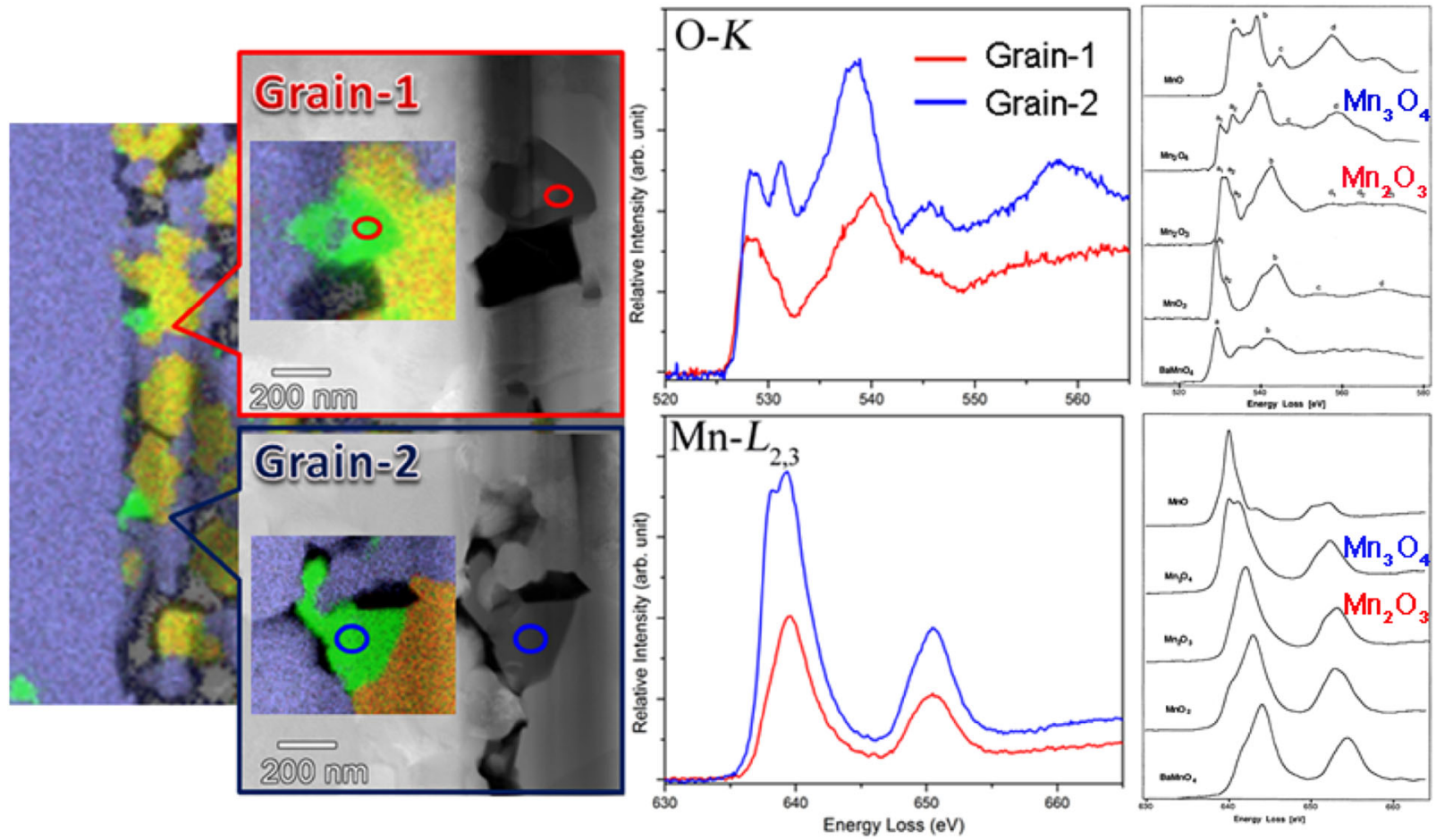

Fig. 6 - (color figure online). EELS fine structure of $\mathrm{O}-K$ edge (top center) and $\mathrm{Mn}-L_{2,3}$ edge (bottom center) from two Mn-oxide grains (top left and bottom left) at the cathode-electrolyte interface of an SOFC operated at $1073 \mathrm{~K}\left(800{ }^{\circ} \mathrm{C}\right)$ for $2000 \mathrm{~h}$ at $388 \mathrm{~mA} \mathrm{~cm}{ }^{-2}$ and 6.4 bara. Anode atmosphere: reformate; cathode atmosphere: 12 pet $\mathrm{O}_{2}, 1.2$ pct $\mathrm{H}_{2} \mathrm{O}$, balance air. Comparison to reference spectra ${ }^{[18]}$ (far right) indicates that grain 1 is $\mathrm{Mn}_{2} \mathrm{O}_{3}$ and grain 2 is $\mathrm{Mn}_{3} \mathrm{O}_{4}$.

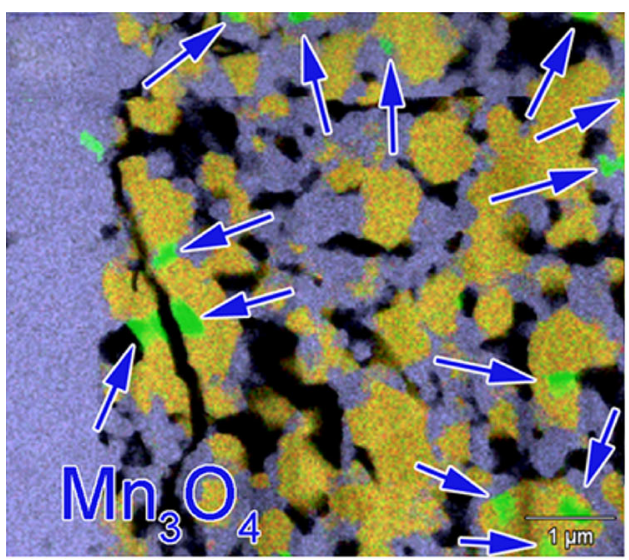

(a)

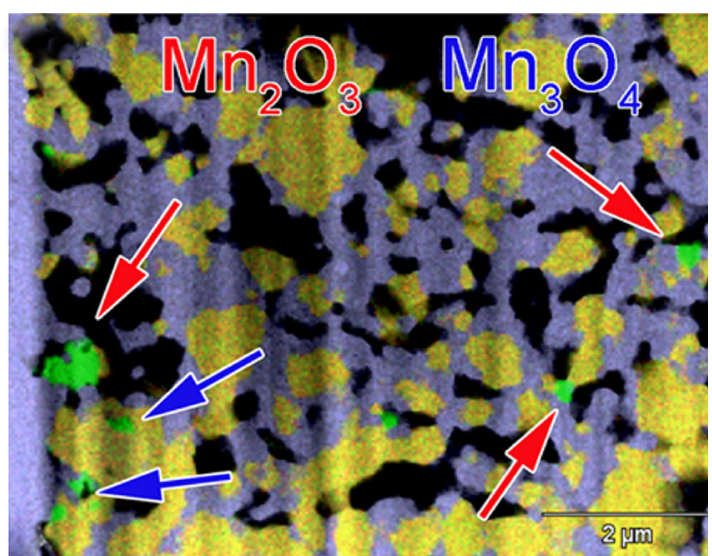

(b)

Fig. 7 - (color figure online). XEDS maps taken near the cathode-electrolyte interface (left edge in each image). (a) Cell of Fig. 3(a), 4 (top), and 5 tested for $1340 \mathrm{~h}$ at $1198 \mathrm{~K}\left(925^{\circ} \mathrm{C}\right.$ ) in 1.2 pct $\mathrm{H}_{2} \mathrm{O}$; EELS identified $\mathrm{Mn}_{3} \mathrm{O}_{4}$ precipitates (arrows). (b) Cell of Fig. 4 (bottom) and 6 tested for $2000 \mathrm{~h}$ at $1073 \mathrm{~K}\left(800{ }^{\circ} \mathrm{C}\right)$ in 1.2 pct $\mathrm{H}_{2} \mathrm{O}$ at $0.388 \mathrm{~A} \mathrm{~cm}^{-2}$; EELS identified both $\mathrm{Mn}_{3} \mathrm{O}_{4}$ (blue arrows) and $\mathrm{Mn}_{2} \mathrm{O}_{3}$ (red arrows). False-color EDS elemental mapping: yellow (LSM); blue (YSZ); and green $\left(\mathrm{Mn}_{y} \mathrm{O}_{x}\right)$.

Table I. Quantitative EELS Data of Mn- $L_{2,3}$ Edge From Grain 1 and Grain 2 (Fig. 6) Compared To Reference Values ${ }^{[19]}$ for $\mathrm{Mn}_{2} \mathrm{O}_{3}$ and $\mathrm{Mn}_{3} \mathrm{O}_{4}$

\begin{tabular}{|c|c|c|c|c|}
\hline & Precipitate $1\left(\mathrm{Mn}_{2} \mathrm{O}_{3}\right)$ & $\mathrm{Mn}_{2} \mathrm{O}_{3}$ & Precipitate $2\left(\mathrm{Mn}_{3} \mathrm{O}_{4}\right)$ & $\mathrm{Mn}_{3} \mathrm{O}_{4}$ \\
\hline$L_{3}(\mathrm{eV})$ & 639.7 & & 639.4 & \\
\hline$L_{2}(\mathrm{eV})$ & 650.5 & & 650.5 & \\
\hline$\Delta E\left(L_{2}-L_{3}\right)(\mathrm{eV})$ & 10.8 & 10.8 & 11.1 & 11.2 \\
\hline$L_{3} / L_{2}$ & 2.5 & $2.4(0.1)$ & 3.0 & $2.8(0.2)$ \\
\hline Valence state & +3 & & $+3,+2$ & \\
\hline
\end{tabular}


perovskite phases. ${ }^{[23,24]}$ Accordingly, with the Mn-rich composition used here, these phases were absent in the cells studied. Above certain values of the $\mathrm{Mn} /(\mathrm{La}+\mathrm{Sr})$ ratio, depending on temperature and oxygen activity, the solubility limit of Mn in LSM would be exceeded, and exsolution of $\mathrm{Mn}_{\mathrm{x}} \mathrm{O}_{\mathrm{y}}$ polymorphs can be expected, as observed here.

In their study of the steam effect, Nielsen and Mogensen ${ }^{[11]}$ combined microstructural evidence and AC impedance results to infer that a reaction product forms between the LSM and YSZ in moist cathode atmospheres, hindering the adsorption of oxygen on the LSM and the charge transfer at the interface. Manybut not all - of the $\mathrm{Mn}_{2} \mathrm{O}_{3}$ and $\mathrm{Mn}_{3} \mathrm{O}_{4}$ particles seen in Figure 6 do coincide with LSM-YSZ interfaces and with TPBs, suggesting that the reaction product inferred by Nielsen and Mogensen may have been the $\mathrm{Mn}_{\mathrm{x}} \mathrm{O}_{\mathrm{y}}$ seen here. On the other hand, Figure 7(a) (the cell operated at $1198 \mathrm{~K}\left(925^{\circ} \mathrm{C}\right)$, which exhibited a negligible steam effect) shows more individual $\mathrm{Mn}_{\mathrm{x}} \mathrm{O}_{\mathrm{y}}$ precipitates than does Figure 7 (b) (the cell operated at $1073 \mathrm{~K}\left(800{ }^{\circ} \mathrm{C}\right)$, which exhibited a significant steam effect). It appears that it is not the total number of $\mathrm{Mn}_{3} \mathrm{O}_{4}$ particles, but the appearance of $\mathrm{Mn}_{2} \mathrm{O}_{3}$, that correlates with the steam effect. If there is a mechanistic relationship between $\mathrm{Mn}_{\mathrm{x}} \mathrm{O}_{\mathrm{y}}$ formation and the steam effect, it does not appear to involve a simple decrease in TPB density: the cell operated at $1073 \mathrm{~K}\left(800{ }^{\circ} \mathrm{C}\right)$ had a rate of ASR increase 10 times greater than that of the cell operated at $1198 \mathrm{~K}\left(925^{\circ} \mathrm{C}\right)$, and it would be hard to argue that Figure 7(b) shows ten times as much loss of TPB due to $\mathrm{Mn}_{\mathrm{x}} \mathrm{O}_{\mathrm{y}}$ formation as Figure 7(a).

The fact that the steam effect in LSM cathodes is more pronounced at lower temperatures may be related to temperature- and atmosphere-related changes in the defect chemistry and electronic structure of LSM. At lower temperatures, the concentration of oxygen vacancies will be reduced, because of both the mass-balance nature of defect equilibria and the tendency of multivalent cations like Mn to exhibit higher oxidation states at low temperatures. Oxygen vacancies are known to be important for oxygen surface exchange on cathode surfaces. The adsorption of moisture from the cathode gas stream to the LSM surface may further increase the
Mn valence state and reduce oxygen vacancy concentrations (especially at the LSM surface) in LSM.

Another factor that would affect the tendency for $\mathrm{Mn}_{\mathrm{x}} \mathrm{O}_{\mathrm{y}}$ to form is the solubility of $\mathrm{Mn}$ in the zirconia phase. $\left(\mathrm{ZrO}_{2}\right.$ acts as another sink for $\mathrm{Mn}$ beyond the solubility limit in LSM.) The Mn-Y-Zr-O phase diagrams determined by Chen et al. ${ }^{[21]}$ show that Mn has a much lower solubility in tetragonal zirconia (such as the $3 \mathrm{YSZ}$ used here) than in cubic zirconia (e.g., 8YSZ).

Backhaus-Ricoult has reported TEM/EELS and XPS analyses of $\mathrm{Mn}$ valences in LSM and in zirconia at LSM/YSZ interfaces. ${ }^{[25,26]}$ Those studies associated the diffusion of $\mathrm{Mn}$ (as $\mathrm{Mn}^{2+}$ ) into YSZ with faster incorporation of oxygen into the electrolyte and improvements in cell performance. Although those studies were conducted in dry cathode atmospheres, it is possible that conditions that stabilize $\mathrm{Mn}$ as $\mathrm{Mn}^{3+}$ in $\mathrm{Mn}_{2} \mathrm{O}_{3}$ (e.g., Figure 7(b)) rather than as $\mathrm{Mn}^{2+}$ in YSZ lead to slower cathode kinetics and higher cathode ASR, thus contributing to the steam effect. Other work by our group (to be reported elsewhere) indicates noticeably lower incidence of $\mathrm{Mn}_{\mathrm{x}} \mathrm{O}_{\mathrm{y}}$ precipitates in LSM-8YSZ cathodes, even with Mn-rich LSM formulations such as the one reported on here.

To further understand free $\mathrm{Mn}_{\mathrm{x}} \mathrm{O}_{\mathrm{y}}$ formation in LSM cathodes during fuel cell operation and its effect on cathode performance, two identical cells with LSM/ zirconia cathodes were exposed at 4 bara to a cathode atmosphere of 1.1 pct $\mathrm{H}_{2} \mathrm{O}$ at $1198 \mathrm{~K}\left(925^{\circ} \mathrm{C}\right)$ for $5 \mathrm{kh}$ (2.5 times longer than the tests illustrated in Figures 4 through 7). One cell (referred to as the reference cell) had no voltage or current applied, while the other cell (referred as the active cell) was operated continuously at $380 \mathrm{~mA} \mathrm{~cm}^{-2}$ (i.e., conditions similar to those of Figure 7(a) except at a 21 pct lower current density and a much longer time). Post-test XEDS maps (Figure 8) show that $\mathrm{Mn}_{\mathrm{x}} \mathrm{O}_{\mathrm{y}}$ precipitates are distributed uniformly across the entire cathode of the reference cell (Figure $8 \mathrm{a}$ ), but these precipitates were concentrated almost exclusively within about $3 \mu \mathrm{m}$ of the electrolyte/cathode interface of the active cell (Figure 8b), i.e., they are more localized than the $\mathrm{Mn}_{\mathrm{x}} \mathrm{O}_{\mathrm{y}}$ precipitates seen in Figure 7(a). Clearly, with or without electrochemical activity, the temperature and atmosphere permit

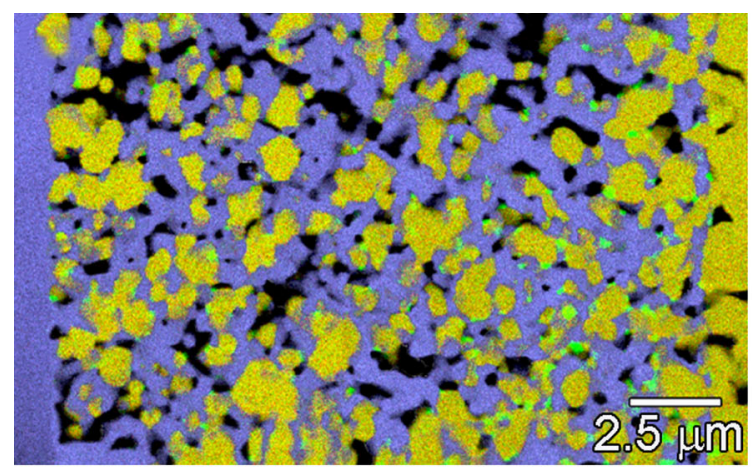

(a)

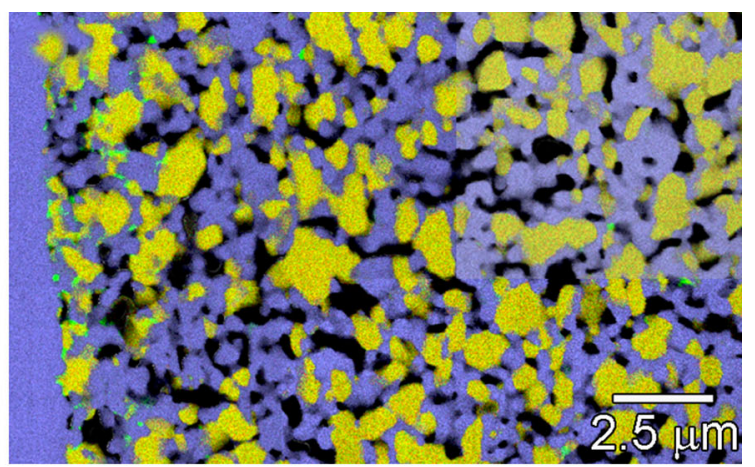

(b)

Fig. 8 - (color figure online). XEDS maps (same colors as Figs. 4 through 7) of the cathodes of identical cells exposed at 4 bara to a cathode atmosphere of 1.1 pct $\mathrm{H}_{2} \mathrm{O}$ at $1198 \mathrm{~K}\left(925^{\circ} \mathrm{C}\right)$ for $5 \mathrm{kh}$. (a) No applied current or voltage. (The single-phase LSM cathode current collector is visible at the far right.) (b) Cell operated continuously at $380 \mathrm{~mA} \mathrm{~cm}{ }^{-2}$. 
existence of $\mathrm{Mn}_{\mathrm{x}} \mathrm{O}_{\mathrm{y}}$ precipitates. Under long-term cell operation, however, $\mathrm{Mn}$ may migrate towards the cathode/electrolyte interface, or a gradient in oxygen activity across the cathode may favor $\mathrm{Mn}_{\mathrm{x}} \mathrm{O}_{\mathrm{y}}$ formation near the cathode/electrolyte interface. The accumulation of free $\mathrm{Mn}_{\mathrm{x}} \mathrm{O}_{\mathrm{y}}$ precipitates near the electrolyte/cathode interface could fill up some of the pores, potentially blocking active TPB sites and reducing cathode performance.

The question of whether $\mathrm{Mn}_{\mathrm{x}} \mathrm{O}_{\mathrm{y}}$ formation and the steam effect are related to cathode kinetics must also consider the report by Armstrong et al. ${ }^{[13]}$ that the surface oxygen exchange rate in LSM increases with decreasing temperature-i.e., counter to the role of temperature in the steam effect. Furthermore, Yasumoto et al. ${ }^{[27]}$ reported that the activity of LSM cathodes decreases as their oxygen nonstoichiometry increases, which is directly related to the local $p_{\mathrm{O}_{2}}$ and temperature. Clearly, differences in test conditions, cathode atmosphere, and cathode formulations between studies will lead to differences in $\mathrm{Mn}_{\mathrm{x}} \mathrm{O}_{\mathrm{y}}$ formation. However, the electrical conductivity of the cathode, the cathode reaction kinetics, and the local electrochemistry, complicate attempts to elucidate the mechanisms behind the steam effect. An important question for future work is whether these $\mathrm{Mn}_{\mathrm{x}} \mathrm{O}_{\mathrm{y}}$ precipitates, and their specific oxidation states, are related (directly or indirectly) to the steam effect, and if so, how the phase stability can be controlled to mitigate the effect.

\section{CONCLUSIONS}

During operation of SOFCs with LSM-based cathodes for up to 2,000 h with $\mathrm{H}_{2} \mathrm{O}$ in the cathode environment, the ASR increases more rapidly at $1073 \mathrm{~K}\left(800^{\circ} \mathrm{C}\right)$ than at $1198 \mathrm{~K}\left(925^{\circ} \mathrm{C}\right)$ (the "steam effect"). XEDS mapping after cell operation revealed formation of $\mathrm{Mn}_{\mathrm{x}} \mathrm{O}_{\mathrm{y}}$ precipitates in the LSM-YSZ cathode, especially near the cathode-electrolyte interface. STEM-EDS line scans showed that the $\mathrm{Mn}_{\mathrm{x}} \mathrm{O}_{\mathrm{y}}$ precipitates contained only trace amounts of other cations. Comparison of the $\mathrm{O}-K$ and $\mathrm{Mn}-L_{2,3}$ edges in the EELS spectra further showed that for the cell operated at $1198 \mathrm{~K}\left(925^{\circ} \mathrm{C}\right)$, only $\mathrm{Mn}_{3} \mathrm{O}_{4}$ was present. In contrast, both $\mathrm{Mn}_{3} \mathrm{O}_{4}$ and $\mathrm{Mn}_{2} \mathrm{O}_{3}$ were present in the cell operated at $1073 \mathrm{~K}\left(800{ }^{\circ} \mathrm{C}\right)$. After operation for $5,000 \mathrm{~h}$ at $1198 \mathrm{~K}\left(925^{\circ} \mathrm{C}\right), \mathrm{Mn}_{3} \mathrm{O}_{4}$ formation was confined almost exclusively to within about $3 \mu \mathrm{m}$ of the cathode-electrolyte interface. While the formation of $\mathrm{Mn}_{2} \mathrm{O}_{3}$ is certainly implicated in the steam effect, definitive evidence that this is the origin of the effect is still lacking.

\section{ACKNOWLEDGMENT}

This material is based upon work supported by the US Department of Energy, National Energy Technology Laboratory under Award Number DE-FE0000303.

\section{DISCLAIMER}

This paper was prepared as an account of work sponsored by an agency of the United States Government. Neither the United States Government nor any agency thereof, nor any of their employees, makes any warranty, express or implied, or assumes any legal liability or responsibility for the accuracy, completeness, or usefulness of any information, apparatus, product, or process disclosed, or represents that its use would not infringe privately owned rights. Reference herein to any specific commercial product, process, or service by trade name, trademark, manufacturer, or otherwise does not necessarily constitute or imply its endorsement, recommendation, or favoring by the United States Government or any agency thereof. The views and opinions of authors expressed herein do not necessarily state or reflect those of the United States Government or any agency thereof, or LG Fuel Cell Systems Inc.

\section{REFERENCES}

1. S.C. Singhal, K. Kendall, eds.: High Temperature Solid Oxide Fuel Cells: Fundamentals, Design, and Applications, Ch. 1, Elsevier, New York, 2003.

2. US Fuel Cell Council (now Fuel Cells and Hydrogen Energy Association), Fuel Cells for Power Generation, 2008 (http://www.fchea.org/core/import/PDFs/Fuel-Cells-for-PowerGeneration-2008.pdf).

3. H. Yokokawa, H. Tu, B. Iwanschitz, and A. Maic: J. Power Sources, 2008, vol. 182, pp. 400-12.

4. S. Lee, N. Miller, H. Abernathy, K. Gerdes, and A. Manivannan: J. Electrochem. Soc., 2011, vol. 158, pp. B735-42.

5. T. Ohrn and Z. Liu: "Rolls Royce Coal-Based SECA Program Update," 26 July 2011 (http://www.netl.doe.gov/publications/ proceedings $/ 11 / \mathrm{seca} / \mathrm{pdf} /$ Tue $\% 20 \mathrm{PM} /$ Ohrn.RRFCS $\% 20$ SECA $\%$ 202011\%20Workshop \%20Final.pdf).

6. E.N. Armstrong, K.L. Duncan, and E.D. Wachsman: J. Electrochem. Soc., 2011, vol. 158, pp. B283-89.

7. A. Hagen, M. Chen, K. Neufeld, and Y.L. Liu: ECS Trans., 2009, vol. 25 , pp. 439-46.

8. S.H. Kim, K.B. Shim, C.S. Kim, J.T. Chou, T. Oshima, Y. Shiratori, K. Ito, and K. Sasaki: J. Fuel Cell Sci. Technol., 2010, vol. 7, pp. 02101-1-02101-6.

9. J. Nielsen, A. Hagen, and Y.L. Liu: Solid State Ionics, 2010, vol. 181, pp. 517-24.

10. A. Hagen, K. Neufeld, and Y.L. Liu: J. Electrochem. Soc., 2010, vol. 157, pp. B1343-48.

11. J. Nielsen and M. Mogensen: Solid State Ionics, 2011, vol. 189, pp. 74-81.

12. R.R. Liu, S.H. Kim, S. Taniguchi, T. Oshima, Y. Shiratori, K. Ito, and K. Sasaki: J. Power Sources, 2011, vol. 196, pp. 7090-96.

13. E.N. Armstrong, K.L. Duncan, and E.D. Wachsman: Phys. Chem. Chem. Phys., 2013, vol. 15, pp. 2298-2308.

14. S.-J. Shih, R. Sharghi-Moshtaghin, M.R. De Guire, R. Goettler, Z. Xing, Z. Liu, and A.H. Heuer: J. Electrochem. Soc., 2011, vol. 158, pp. B1276-80.

15. Z.L. Wang, J. Bentley, and N.D. Evans: Micron, 2000, vol. 31, pp. 355-62.

16. Z.L. Wang, J.S. Yin, and Y.D. Jiang: Micron, 2000, vol. 31, pp. $571-80$.

17. D.H. Pearson, C.C. Ahn, and B. Fultz: Phys. Rev. B, 1993, vol. 47, pp. 8471-78.

18. H. Kurata and C. Colliex: Phys. Rev. B, 1993, vol. 48, pp. 2102-08.

19. H.K. Schmid and W. Mader: Micron, 2006, vol. 37, pp. 426-32.

20. D.R. Gaskell: Introduction to the Thermodynamics of Materials, Ch. 12, 4th ed., Taylor \& Francis, New York, 2003.

21. M. Chen, B. Hallstedt, and L.J. Gauckler: Solid State Ionics, 2005, vol. 176, pp. 1457-64. 
22. H.J. Wang, Y.L. Liu, M. Chen, J.R. Bowen, and L. Theil Kuhn: $J$. Power Sources (submitted).

23. M. Gödickemeier, K. Sasaki, L.J. Gauckler, and I. Riess: Solid State Ionics, 1996, vols. 86-88, pp. 691-701.

24. A. Mitterdorfer and L.J. Gauckler: Solid State Ionics, 1998, vol. 111 , pp. 185-218.
25. M. Backhaus-Ricoult: Solid State Ionics, 2006, vol. 177, pp. 2195-2200.

26. M. Backhaus-Ricoult, K. Adib, T. St. Clair, B. Luerssen, L. Gregoratti, and A. Barinov: Solid State Ionics, 2008, vol. 179, pp. 891-95.

27. K. Yasumoto, N. Mori, J. Mizusaki, H. Tagawa, and M. Dokiya: J. Electrochem. Soc., 2001, vol. 148, pp. A105-A111. 